\title{
Assessing the economic benefit share of Woodsland Joint Stock Company and Forest growers household at Tuyen Quang Province, Viet Nam
}

\author{
Do Hai Yen \\ Economics and Business Administration Faculty, Tan Trao University, Tuyen Quang, Vietnam
}

\begin{abstract}
How to cite this paper: $\mathrm{D}$. $\mathrm{H}$ Yen (2020) Assessing the economic benefit share of Woodsland Joint Stock Company and Forest growers household at Tuyen Quang Province, Viet Nam. International Journal of the Science of Food and Agriculture, 4(1), 65-72.

DOI:10.26855/ijfsa.2020.03.010

Received: January 6,2020

Accepted: February 16,2020

Published: March 9,2020

*Corresponding author: Do Hai

Yen, Economics and Business

Administration Faculty, Tan Trao

University, Tuyen Quang, Vietnam.

Email:dohaiyentq@gmail.com
\end{abstract}

\begin{abstract}
The article aims to assess the reality of afforestation linkage model, with a particular focus on its economic, between Woodsland Joint Stock company and local forest growers in Tuyen Quang Province, Viet Nam. Systematic and participatory approach method were used in this study. The results revealed that incomes from forest of households who participated in the linkage is higher about $10-18 \%$ than non-participating growers. However, the hectare of forest plantation in the model has been small so far in Tuyen Quang Province. In order to develop the afforestation linkage model, the study recommended feasible solutions such as: enhancing the awareness about benefits of model to forest growers; developing permanent and effective linkage between company and households; local authorities should play an important role in the linkage model by connecting and supporting the establishment of the two parties.
\end{abstract}

\section{Keywords}

Afforestation linkage, wood processing company, plantation household, forest, model, Tuyen Quang, Viet Nam

\section{Introduction}

Though there is a dire need of conservation of natural forests for the lucrative environment and social protection, but correspondingly the industrial forest plantation is also required. These industrial forests are not only necessary to escalate the forest area but also to meet the demand of wood products for wood industry. One of the reports of FAO (2001)[1], has demonstrated that "industrial plantations are grown only about $5 \%$ of the total forest area but provide $35 \%$ of the world's wood supply". Owing to burgeoning population and inclining of developing economies to developed economies, the demand of timber products is increasing. Besides the involvement of companies, many small-scale farm have evolved in industrial plantation of forest. The farm timber producers have potentials in providing timber for wood materials market, especial in contractual market (corporate-smallholder partnerships).

Forest plantation plays pivotal role in rural livelihoods especially in some highland provinces of Vietnam. It provides a paved way to diminish an unemployment and poverty in the rural area, protect the ecological environment and to meet the timber material demand for wood processing industry[2]. Tuyen Quang is a mountainous province located in the north of Vietnam whose $76 \%$ of land area is covered with forest [3]. Hence, making a living through planting forest has been implemented by farmers in Tuyen Quang since decades. In the recent years the Linkage Model was launched and cascade rapidly to develop nexus between wood processing 
enterprises and local household growers involved in timber plantation. Those growers who participate in the Linkage Model are benefactor by wood companies which provide them capital investment, management ability, transfer technology and capacity building as well as market opportunities. In response, the timber household producers provide forest land, labour and trees management [5]. One of the best empirical examples of the linkage models in Tuyen Quang province is the joint venture between Woods Land Company and local households in developing afforestation following Forest Stewardship Council's standards (FSC). The model is successfully executed since 2015, based on the establishment of Woods land company in Tuyen Quang Province, and has been considered as the best effective linkages because it emerged spontaneously due to timber product market demand rather than regulatory intervention from government or local authorities. Subsequently, in order to maintain and develop the model for long term it is necessary to assess the advantages as well as difficulties in the implementation, operation and organization of the linkage model. Therefore, this research endeavour is designed to capture the economic benefits and challenges faced by the timber growers and wood company. The specific objective of this research paper include: 1) investigate the role and participation of both parties in the linkage model; and 2) assess the economic benefits, social and environmental performance of the model..

\section{Materials and Methods}

\subsection{Study Site}

This research study was carried out in two districts namely Yen Son and Son Duong of Tuyen Quang Province, Viet Nam. These two districts were choosen because both districts are deemed as iconic districts among seven districts in the province for the abundance production of timber. Besides, the percentage of FSC-certified forests that belongs to the linkage model of the two selected district is large. According to the available data reported in Table 1, the area of FSC certified forest of Yen Son District had reached 9.270 ha (40\%) and Son Duong was 4.951 ha $(21,6 \%)$ of the total FSC forest area of the province.

Table 1: Information on Land Area, Forest Cover and FSC Certified Forest in Tuyen Quang Province

\begin{tabular}{cccc}
\hline Province/ District & Land Area (ha) & Forest Cover (ha) & FSC Certified Forest (ha) \\
\hline Tuyen Quang Province & 586.790 & 441.620 & 22.954 \\
Yen Son District & 113.301 & 82.895 & 9.270 \\
Son Duong District & 78.795 & 43.188 & 4.951 \\
\hline
\end{tabular}

Source: Tuyen Quang Department of Statistic, 2018.

Forest plantation in Tuyen Quang Province mostly comprises species of Eucalyptus and Acacias [4]. By the first six months of 2019, according to the statistic of Tuyen Quang Forest Protection Department, the timber exploitation from growers has reached $787.254 \mathrm{~m} 3$ accounting for $94 \%$ of the same time 2018 . This result has relatively meet the need of timber demand for wood processing companies in the province.

\subsection{Sampling and data collection}

This research endeavor encompassed both primary and secondary data. Primary data were learned through interview schedule by face to face interview technique. The total of 120 forest plantation households was chosen that comprised of 80 growers currently participating in the linkage model and 40 non-participated growers. The study used simple random sampling technique to select households, while purposive sampling was employed to select the key informants for interviewing such as 08 local officials who are responsible for forest management at province, district, commune, and village levels; 02 officials from Woodsland company who acted as experts for this linkage model. Secondary data includes information about the status of planted forest in the province, the hectare of forest plantation with FSC certification, and annual business reports of Woodsland Joint Stock company, State management documents and reports of Agriculture and Rural Development Department and Forest Protection Department.

In order to approach and achieve the research objectives, the study used systematic and participatory approach 
methods. Descriptive statistics were used to describe the current sistuation of FSC certified forest plantation development. In addition, cost benefit analysis and comparative analysis were used to assess economic benefits as well as advantages and disadvantages when implementing the linkage model.

\section{Results and Discussion}

\subsection{The Linkage Model between Woodsland Joint Stock Company and Forest Plantation Households}

Woodsland Joint Stock company has become one of the main wood product suppliers of IKEA Group (IKEA) in Vietnam since 2014. IKEA is one of the largest furniture retailers in the world. Becoming IKEA's supplier, the processing companies have opportunities to obtain loans from IKEA or borrow in advance if there is demand. In addition, its suppliers will be guaranteed long-term orders for $3-5$ years.

The main products were produced from Woodsland are wooden furniture. The company currently has four factories with approximately 1.500 employees. On average, Woodsland supplies IKEA about 50 containers of wood products per month [5]. With the consumption demand of over $250.000 \mathrm{~m} 3$ timber material per year for processing factory, the company need to exploit at least 2.500 ha of FSC certified forest plantation, in which the trees must reach 7 years at least. Currently, Woodsland is the largest FSC certified timber consuming company in Tuyen Quang province. Since the company was located in Tuyen Quang Province, under the positive support from local authorities, they tried to connect with local households to develop a large supply of timber material that achieved FSC certification following requirement of IKEA for all their wood products sourced in Vietnam and sold in international markets. They links to households through an agreement in planting FSC certified acacia.

Afforestation linkage model involves the stakeholders as bellow (Figure 1):

1. Woodsland Joint Stock Company: responsible for manufacturing wooden products in the right quantity, quality and time to supply to IKEA; poviding financial and technical support in afforestation to households; admin in the linkage model.

2. Timber grower households: responsible for afforestation and supplying timber material to Woodsland company through Chain of Custody $(\mathrm{CoC})$ sawmills of the company. In order to join in the scheme with company, the households must show their letter on forest land status, especially if there were historical conflicts in the areas.

3. Forestry Cooperative: responsible for gathering households into groups and representing for them to connect with the company.

Additionally, the linkage model is supported by local authorities such as People's Committee from provincial level to the commune level and Department of Agriculture and Rural Development. They provide administrative supports such as helping establish and facilitating the linkage implementation. They also play an important role in introducing and raising awareness about FSC certified forest among farmer households and encouraging them to paticipate in the model.

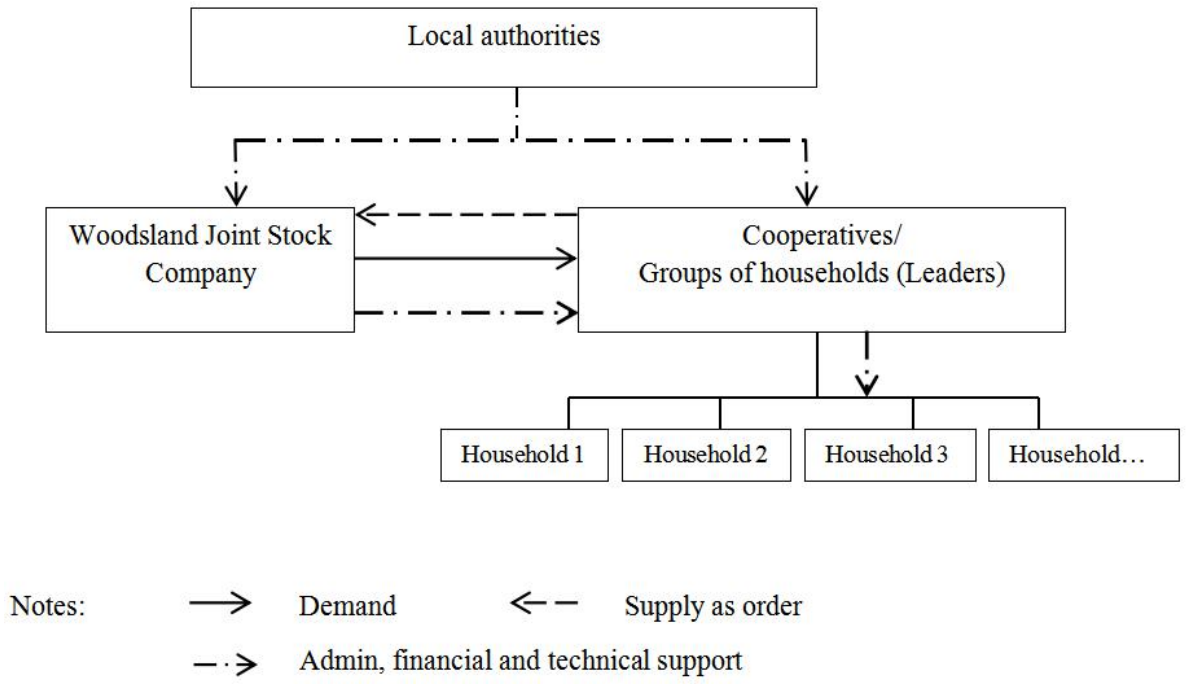

Figure 1. The Linkage Model between Woodsland Joint Stock Company and Forest Plantation Households 


\subsection{Rights and obligations of each stakeholders in the linkage model}

In this model, the company does not sign a commercial contract with individual households. They sign supportive contracts with a designated member of each household groups or representative of cooperatives. The contract focusses mostly on describing the responsibilities of the growers in planting trees following FSC criterias and the company will sponsor $100 \%$ fee of forest evaluation to achieve FSC certificate.

The rights and obligations of company and their partners joining into the agreements are outlined in Table 2 as bellow:

Table 2: Rights and Obligations of parties in the linkage model

\begin{tabular}{|c|c|c|}
\hline & Rights & Obligations \\
\hline $\begin{array}{l}\text { Forest plantation } \\
\text { households }\end{array}$ & $\begin{array}{l}\text { - To be supported for free with } 100 \% \text { fee of } \\
\text { evaluating and achieving FSC certificate } \\
\text { for forest plantation. } \\
\text { - Oportunities to approach loans with less } \\
\text { or free interest rates. } \\
\text { - Improve the knowledge in technology, } \\
\text { silvicultural training for forest } \\
\text { establishment and maintenance. } \\
\text { - Safety output market for timber harvest } \\
\text { and increasing income }\end{array}$ & $\begin{array}{l}\text { - To comply tightly all technical requirements on } \\
\text { afforestation according to FSC criterias to ensure certified } \\
\text { timber materials } \\
\text { - Lasting the cycle of trees (at least for } 7 \text { years) to obtain the } \\
\text { large-diameter size of wood. } \\
\text { - To give priority in selling timber to COC sawmills of the } \\
\text { company or to the company directly }\end{array}$ \\
\hline Cooperatives & $\begin{array}{l}\text { - To be received FSC evaluation costs from } \\
\text { the company and implement it to } \\
\text { households. } \\
\text { - To be trained and accessed new scientific } \\
\text { and planting techniques following FSC } \\
\text { standars. } \\
\text { - To be updated reliable information } \\
\text { regarding good seedlings to introduce with } \\
\text { household growers. }\end{array}$ & $\begin{array}{l}\text { - to support househods in preparing forest documents for } \\
\text { FSC evaluation } \\
\text { - To help company to check and make a harvest plan } \\
\text { annually. Being a bridge between company and households. } \\
\text { - To assist households in havesting and guide them to sell } \\
\text { timber for company's sawmills }\end{array}$ \\
\hline $\begin{array}{l}\text { Woodsland Joint } \\
\text { Stock Company }\end{array}$ & $\begin{array}{l}\text { - Having the stable source of timber } \\
\text { material inputs that meet the requirement of } \\
\text { IKEA wooden products } \\
\text { - Being initiative management in timber } \\
\text { material sources and reducing the imported } \\
\text { inputs. }\end{array}$ & $\begin{array}{l}\text { - To combine with cooperatives, training growers in } \\
\text { developing and managing the forest following the } \\
\text { requirement of FSC. } \\
\text { - To adise on organization and operation of household groups } \\
\text { such as: meetings, monitoring forest development } \\
\text { - To sponsor } 100 \% \text { for free the forest evaluation cost to } \\
\text { achive FSC certification. } \\
\text { - To commit to purchase FSC certified timber when } \\
\text { harvesting at a price higher about } 10-18 \% \text { at least than } \\
\text { market price of non-certified wood at the time of transaction. }\end{array}$ \\
\hline
\end{tabular}

Source: The supportive contract, Woodsland company 2018

\subsection{Effectiveness of the linkage model}

\subsubsection{Economic benefits}

\section{For Woodsland Joint Stock Company}

Woodsland company has been cooperating with local forest plantation since 2015. Accordingly, the most timber product supplied by households to company is roundwood and lumber. The volume of timber consumption following agreement are shown at Table 3. 
Table 3: Total volume of timber consumption of Woodsland company (2015-2019)

\begin{tabular}{ccccc}
\hline \multirow{2}{*}{ Year } & \multicolumn{2}{c}{ Total Supply $\left(\mathrm{m}^{3}\right)$} & Total demand $(\mathrm{m} 3)$ & Short $(-)$, Redundant $(+)$ \\
& Roundwood & Lumber & 160.000 & -118.000 \\
2015 & 28.000 & 14.000 & 190.000 & -140.000 \\
2016 & 34.500 & 15.500 & 220.000 & -140.000 \\
2018 & 42.000 & 38.000 & 235.000 & -133.500 \\
30 June, 2019 & 76.500 & 25.000 & 250.000 & -208.000 \\
\hline
\end{tabular}

Source: Timber Department, Woodsland company 2019

Table 4: Economic impacts of FSC-certified and Non-FSC certified plantation households

\begin{tabular}{|c|c|c|c|c|}
\hline & \multicolumn{2}{|c|}{ FSC certified plantation households in the linkage } & \multicolumn{2}{|c|}{ Non FSC certified plantation households } \\
\hline Planting density & \multicolumn{2}{|c|}{$2000-2500$ roots per ha } & \multicolumn{2}{|c|}{$2500-3300$ roots per ha } \\
\hline Harvest cycle & \multicolumn{2}{|r|}{10 years } & \multicolumn{2}{|c|}{7 years } \\
\hline Indicator & $\begin{array}{l}\text { Value per ha } \\
\text { (million VND) }\end{array}$ & Note & $\begin{array}{l}\text { Value per ha } \\
\text { (million VND) }\end{array}$ & Note \\
\hline $\begin{array}{l}\text { Revenue from } \\
\text { selling pruning trees } \\
\text { in the } 4 \text { th or } 5 \text { th year }\end{array}$ & 0 & & $6-8$ & $\begin{array}{l}\text { Pruning wood price is } 0,9 \\
\text { million per } \mathrm{m}^{3}\end{array}$ \\
\hline $\begin{array}{l}\text { Revenue from } \\
\text { selling pruning trees } \\
\text { in the } 5 \text { th or } 6 \text { th year }\end{array}$ & $10-12$ & $\begin{array}{l}\text { Pruning wood price is } 1 \text { million } \\
\text { per } \mathrm{m}^{3}\end{array}$ & $12-16$ & $\begin{array}{l}\text { Pruning wood price is } 1 \\
\text { million per } \mathrm{m}^{3}\end{array}$ \\
\hline $\begin{array}{l}\text { Revenue from } \\
\text { selling timber at } \\
\text { harvest }\end{array}$ & $170-204$ & $\begin{array}{l}\text { Total revenue for } 100-120 \mathrm{~m}^{3} \\
\text { of logs and } 30-40 \mathrm{~m} 3 \text { of } \\
\text { woodchips. } 70 \% \text { of exploited } \\
\text { wood is sold as sawnwood; } \\
30 \% \text { as woodships. Selling } \\
\text { price is } 1,4 \text { million VND per } \mathrm{m}^{3}\end{array}$ & $90-120$ & $\begin{array}{c}\text { Total revenue for } 60-80 \\
\text { m3 of logs or woodchips. } \\
\text { Average price is } 1,2 \\
\text { million VND per } \mathrm{m}^{3}\end{array}$ \\
\hline Total revenue & $180-216$ & & $108-144$ & \\
\hline Total cost & $50,3-60,3$ & $\begin{array}{l}\text { Equivalent costs approx } 30 \% \\
\text { including varieties, fertilizers, } \\
\text { labor salary and equipment for } \\
\text { harvest (outsourced) and } \\
\text { transportation. Excluding } \\
\text { household labor and fee for } \\
\text { achieve FSC certification }\end{array}$ & $35-45$ & $\begin{array}{l}\text { Equivalent costs approx } \\
30 \% \text { including varieties, } \\
\text { fertilizers, labor salary for } \\
\text { harvest (outsourced) and } \\
\text { transportation. Excluding } \\
\text { household labor salary }\end{array}$ \\
\hline Total profit & $129,7-155,7$ & Within 10 years & $73-99$ & Within 7 years \\
\hline $\begin{array}{l}\text { Annual average } \\
\text { profit }\end{array}$ & $13-15,6$ & & $10,4-14,1$ & \\
\hline
\end{tabular}

Source: Calculated from Survey Data, 2019

The linkage model ensures that processing company is able to maintain a steady supply of FSC certified timber for manufacturing. By promoting sustainable domestic timber material sourcing, the linkage helps company reduce its dependency on imported timber from other countries. Although there is an increasing volume of 
FSC-certified timber supplied to the company, it has not meet the demand of raw materials for the processing factory. The quantity of exploited timber has just reached about $30-40 \%$ of company manufacturing capacity. Through the survey, the study has found that only $76 \%$ and above of the households, who participated in the linkage, followed the commitments and sold timber to the company. The remainders violated the contract and thus sold timber elsewhere. This poses a very real financial risk to company if the sistuation happens very often. In fact, there are not any clauses in the agreements between woodsland and households require that the households have to sell timber to the company at harvesting. The company's leader interviewed stated the contractual provision on the sale of timber will hinder the development of the agreement and ability participating the linkage of new growers.

\section{For Forest Plantation Households}

Following the obligations in the contract with households, Woodsland company commit to purchase all FSC-certified timber materials at a minimum price 10-18\% higher than the market price for non-certified FSC timber of the same type. Accordingly, the average profit per hectare of acacia plantation of each household is approximately 170 - 204 million VND meanwhile the average profit from selling timber of non- FSC certified and non participated in linkage households is $90-120$ million VND. Table 4 provides a comparison about revenues and costs between FSC forest plantation households in the linkage and non FSC certification.

The costs of forest assessments prior to granting FSC certification valued in 5 years is about US\$28,000, including an initial evaluation cost (about US\$ 8000) and annual assessment costs for subsequent four years about US\$ 5000 per year. However, the households have not had to pay for it so far. It is sponsored by Woodsland company. Participating the linkage, plantation growers not only obtain the reliable cash flow, increase income and reduce the output market risks through ensure sales but also have much oportunities to approach loans with less or free interest rates. Households were also able to receive silvicultural physical support and advice with skills in treecrop management and establishment from the company [5].

\subsubsection{Scocial Impacts}

According to the statistic of the Department of Agriculture in Tuyen Quang, up to now, more than $70 \%$ of the province's labourers are agricultural and forestry workers, of which, forestry accounts for about $13 \%$. The linkage model provided opportunities for community members, whether a tree grower or not, to work in the plantations and gave them valuable practical experience on cultivation practices. Moreover, community members could receive assistance from the company for social funds and road infrastructure under outgrowing program. Thereby, it enables for society to develop sustainable economic in long term. Developing afforestation following Forest Stewardship Council's standars, the application of the provisions of labor law compliance, ensuring labor safety and hygiene in all stages of harvesting and manufacturing process helps workers better protect their health. Most of the respondents appreciated that the partnerships generated other benefits, $93 \%$ stated they received economic benefits and $61 \%$ stated they were happy with social benefits.

The linkage model has motivated the local government to promote recognition of land tenure by granting land use certificates to forest plantation households. More secure tenure lands help reduce conflict among communities and create a peace of mind for households to invest in production proactively. In 2018, there were additional 519 households in Tuyen Quang receiving forest land use certificate [3].

\subsubsection{Environmental Impacts}

Afforestation linkage between Woodsland company and households has contributed to improve the local ecological environment by increasing the new forest area annualy. By the end of 2018, Under the agreement, communities in Son Duong and Yen Son District planted more than 9400 hectares of new forest, increase the ratio of forest cover up to $75 \%$ of the total districts area [3]. It has contributed significantly to the improvement of underutilized agricultural land with poor access and low productivity, protect soil and water for local. In addition, the linkage model requires compliance with a number of environmental standars such as: prohibition of clear-cut exploitation of large areas and large - scale burning of forest cover; prohibition on using chemicals when tending forests; no littering, no grazing in the forest; erosion and water sources protection. These standars significantly help to protect surounding environment in communities.

\subsection{Challenges to maintain and develop the linkage model}

Since establishing, it is considered that the linkage has the potential in offering stable benefits for all parties 
involved. However, in order to maintain and develop effectively the model for long-term viable partnerships, the linkage model will face these following challenges:

Currently, tree growers do not have to pay for the costs of granting FSC certification. Woodsland company is supporting technical and financial to form and operate forest plantation household groups. They also sponsor FSC certificate assessment. Hence, these are not included in households' production price structure. In Tuyen Quang Province, most tree growers (70\%) live in moutainous areas where people are still poor and their livelihoods base on agricultural production activities. According to informations obtained from households, they are able to receive more economic benefit from selling FSC-certified timber than non-certified. However, $80 \%$ households interviewed reveal that they might be unwilling to participate in the linkage with company if they were required to bear the certification costs.

Challenges to complying FSC requirements: FSC standars comprise 10 principles and 56 criterias. The study found that the sistuation of FSC certified forestlands, which average from 1-3 ha, are scattered among non-certified in some areas. Accordingly, it is not easy to manage and harvest within these framented landscapes, and those who facing this found it more difficult and challenge to comply with FSC requirements. For example, tree growers who did not take part in the linkage and plant trees following normal way, not plant in accordance with FSC refulations, may use pesticides outside the permitted list or burn vegetation indiscriminately. These have had a direct impact on certified forest areas arround. In addition, It was difficult to change perception of households practicing traditional farming techniques. Most tree growers (89\%) have experienced in planting forest for over 15 years and they are 45 years old and above in average and their education level is low ( $75 \%$ graduated highschool and under), therefore, it is not easy to change the production habits for them. Information from interviewing commune officials and staff from Woodsland company reveals that they found it difficult when introducing, mobilizing and persuading new households to participate in the linkage model and comply all FSC requirements.

The cooperative relationship between company and timber households may face risk related to breaking contract from households. For example, if households fail to comply with terms and conditions in the contract such as: selling timber to other companies (the contract did not or trees are cut and sold before the required growth cycle, it is difficult for company to deal the problem with a large number of households. Because they can not suggest legal proceedings with community groups so in this case the role of local authorities is very necessary. However, a little research shown the role of third parties when risks happened. One representative from company shared: households are always the side that give the final decision about choosing which company to sell trees for. In stead of working with aims tending to social development, they think for themselves and give priority to their own benefit than other things. Thus, there are many members in each family so they need money fast for some urgent needs such as: money for their children at school, for some treatments in the hospital. As a result, they can not wait untill the harvest time as expectation because they do not have many cash-flow supplies. In these cases, the company accepted this risk and stated "they never cooperate with them anymore in the future"

\section{Conclusion and Recommendations}

The linkage model between Woodsland company and local forest plantation households has made important contributions to promote afforestation with FSC standars in Tuyen Quang Province. Study results indicate that company - forest plantation households agreements can be profitable. According to respondents, household profit result from FSC certified forest (annual average 13 - 15,6 million VND) is higher than non-certified (annual average 10,4 - 14,1 million VND). The linkage model also brings significantly benefits to social and environmental improvement. However, there are three main challenges that the model has to face including: 1) The unwillingness to participate in the linkage model of households in the future if they have to pay for the costs associated FSC certification; 2) Challenges to complying FSC requirements in long term; 3) Contractual enforcement issues from households may directly influence the company's manufacturing and thereby effect on the relationship between company and timber households. In order to promote this linkage model, some recommendations for better partnerships are propose:

- Each household group should set up a membership costs which raise funds for associations' annual activities including FSC certification expenses. This can be feasible because the costs of FSC assessment depend on the time required for assessment. Hence, the cost per unit of forest area will be less if the assessment covers a 
large of geographic area and vice versa. At the same time, the company should continue enhancing the awareness of new households about the linkage and encouraging them in participating the model.

- Enhance the role of coperatives and each household group's leader in monitoring the implementation of household members in complying FSC requirements. Besides, they should also propagandise and encourage new households join in the model.

- Strengthen the role of local authorities not only for creating a favourable conditions to promote the linkages and bring trust to companies, but also having stronger sanctions to deal with the unexpected problems regarding risks when the households break contract.

- Future research on the afforestation linkage model following FSC standars should study more relevant expenditures as well as the potential of benefits from the model to all parties such as: rate of growth of the company or changes in households incomes when participating the linkage model.

\section{References}

[1] FAO. 2001. Global forest resources assessment 2000: main report. FAO Forestry Paper No. 140. Rome.

[2] To Xuan Phuc. 2017. Linkages in wood industry: Incresing opportunities, reducing risks for the sustainable development. (in Vietnamese) Retrieved from:

http://goviet.org.vn/upload/aceweb/content/Lien\%20ket\%20trong\%20nganh\%20che\%20bien\%20go,\%20tang\%20o\%20hoi\%20giam \%20rui\%20rol..pdf accessed on 13.2.2018

[3] Tuyen Quang Department of Statistic .2018. Tuyên Quang statistical Report monthly. Tuyen Quang, Vietnam. (in Vietnamese)

[4] Tuyen Quang Forest Protection Department. 2018. Statistic annual report on forest plantation in Tuyen Quang province. (in Vietnamese)

[5] Woodsland Joint Stock Company. 2019. Statistics annual report on production and business sistuation. (in Vietnamese)

[6] J.Mayers. 2000. Company-community forestry partnerships: a growing phenomenon. Unasylva 200. Vol.51 33-41, FAO, Rome. 